\title{
EFFECTIVENESS OF EDUCATION SESSION ON KNOWLEDGE ABOUT THE USE OF NEEDLESTICK AND SHARP INJURY AMONG PARAMEDICS AT THE COMMUNITY HEALTH CENTER IN BANTUL, YOGYAKARTA
}

\author{
Kusbaryanto, Febriani \\ Department of Public Health, Faculty of Medicine and Health, \\ Universitas Muhammadiyah Yogyakarta
}

\begin{abstract}
Background: Medical workers are at a higher risk for needlestick and sharp injury, particularly one involving infected blood and other body fluid. It is, therefore, necessary to apply standard precaution to reduce medical injury in the health facilities. This study aimed to determine the effect of education on knowledge about the use of needlestick and sharp injury among paramedics at the community health centers in Yogyakarta.

Subjects and Method: This was a quasi-experiment study before and after with control group design. It was conducted at the community health center in Bantul, Yogyakarta. A sample of 30 paramedics was divided into 15 paramedics in the experimental group and 15 paramedics in the control group. The independent variable was education about needlestick and sharp injury. The dependent variable was knowledge about needlestick and sharp injury, measured by questionnaire. The difference in test results between experimental group and control group, both before and after the education session, were tested by Mann-Whitney test.

Result: Knowledge about the risk of needlestick and sharp injury before the education session were comparable between the experimental group and the control group $(\mathrm{p}>$ 0.05). Knowledge after the education session was higher in the experimental group (Mean= 2.33; $\mathrm{SD}=0.49$ ) than the control group (Mean=2.00; $\mathrm{SD}=0.38)$, and it was statistically significant $(\mathrm{p}=0.001)$.

Conclusion: Education is effective to improve knowledge about the risk of needlestick and sharp injury among the paramedics working at a community health center.
\end{abstract}

Keywords: effectiveness, education, needlestick, sharp injury, knowledge, paramedics

\section{Correspondence:}

Kusbaryanto. Department of Public Health, Faculty of Medicine and Health, Universitas Muhammadiyah Yogyakarta. Jl. Brawijaya, Ngebel Tamantirto Kasihan, Bantul, Yogyakarta. Email: koesbary@yahoo.co.id. Mobile: 08121586334. 